\title{
Evaluation of Pre-harvest Microbiological Safety of Blueberry Production With or Without Manure-Derived Fertilizer
}

\author{
Xiaoye Shen', Lina Sheng', Chris Benedict ${ }^{2}$, Chad E. Kruger ${ }^{3}$, Yuan Su', \\ Elizabeth Schacht ${ }^{2}$, Yifan Zhang ${ }^{4}$ and Mei-Jun Zhu ${ }^{1 *}$
}

${ }^{1}$ School of Food Science, Washington State University, Pullman, WA, United States, ${ }^{2}$ Whatcom County Extension, Washington State University, Bellingham, WA, United States, ${ }^{3}$ Center for Sustaining Agriculture and Natural Resources, Washington State University, Pullman, WA, United States, ${ }^{4}$ Department of Nutrition and Food Science, Wayne State University, Detroit, MI, United States

OPEN ACCESS

Edited by:

Eugenia Bezirtzoglou, Democritus University of Thrace,

Greece

Reviewed by:

Hiroshi Asakura,

National Institute of Health

Sciences (NIHS), Japan

Esmeralda Rangel Vargas, Autonomous University of the

State of Hidalgo, Mexico

*Correspondence: Mei-Jun Zhu meijun.zhu@wsu.edu

Specialty section: This article was submitted to

Food Microbiology,

a section of the journal

Frontiers in Microbiology

Received: 01 October 2019 Accepted: 24 December 2019 Published: 14 January 2020

Citation:

Shen $X$, Sheng L, Benedict $C$, Kruger CE, Su Y, Schacht E, Zhang $Y$ and Zhu M-J (2020) Evaluation of Pre-harvest Microbiological Safety of Blueberry Production With or Without Manure-Derived Fertilizer. Front. Microbiol. 10:3130. doi: 10.3389/fmicb.2019.03130
Blueberry is an important commodity in Washington State, which was one of the leading blueberry producers in the United States. As a ready-to-eat fruit, blueberry has no or limited post-harvest processing, highlighting an imperative need to evaluate its microbial safety during pre-harvest practice. This study accessed the microbiological safety of blueberry produced in a commercial blueberry field applied with or without manure-derived ammonium sulfate (AS) fertilizer in a 2-year study. Indicator microorganisms of total coliforms and generic E. coli, Shiga toxin-producing Escherichia coli (STEC), Salmonella, and Listeria monocytogenes were monitored in fertilizer, soil, foliar, and blueberry fruit samples by culture methods for each production season. The population of total coliforms in soils was 3.17-3.82 Log $_{10}$ $\mathrm{CFU} / \mathrm{g}$, which was stable throughout the production season and similar between two cropping seasons. Generic E. coli in soils remained at very low levels throughout the 2018 production season. Total coliforms or generic E. coli was not detected in fertilizer, foliar, and blueberry fruit samples collected in both 2017 and 2018 production seasons. STEC and L. monocytogenes were below the detection limit in fertilizer, soil, foliar, and blueberry fruit samples collected in both production seasons. Salmonella was not detected except for soil samples collected pre- and post-fertilizer application in the 2018 cropping season. Collectively, data indicated, under good agricultural practices, blueberry fruits produced in the field with or without manure-derived AS fertilizers had no microbiological safety concern.

Keywords: manure-derived ammonium sulfate, blueberry, coliform, Shiga toxin-producing Escherichia coli, Salmonella, Listeria monocytogenes

\section{INTRODUCTION}

The United States is the largest blueberry producer in the world, and Washington State is one of the leading blueberry producers in the United States (Evans and Ballen, 2014). Blueberries are grown in an open environment and subjected to potential contamination of foodborne pathogens from the environment including soil, irrigation water, wild animals, and runoff water 
from the surrounding cattle farms during production like other fruits (Doyle and Erickson, 2008). In addition, blueberries as ready-to-eat fruits usually have no or limited antimicrobial interventions during post-harvest processing/packing or before consumption. This is also true for blueberries that are individually quick frozen, which is the most common market avenue for northwestern Washington producers, as there is no kill step during processing. Any contamination during blueberry production and pre-harvest handling can pose a food safety threat to consumers. Blueberry is listed in the top 10 riskiest foods by the U.S. Food and Drug Administration (FDA) (CSPI, 2009). In fact, fresh blueberries were linked to a Salmonella Newport outbreak in 2010 (Miller et al., 2013). Fresh and frozen blueberries and other berry products have been involved in multiple recalls due to potential contamination of foodborne pathogens including Shiga toxin-producing Escherichia coli (STEC) (Luna and Mody, 2010), Salmonella (Larsen, 2018), Listeria monocytogenes (FDA, 1998), and viruses including norovirus and hepatitis A virus (FDA, 2019a,b). Controlling and minimizing pre-harvest contamination is considered as one of the key aspects of microbiological safety for blueberry production.

Raw or processed manures are commonly used as soil amendments for blueberry production (Benedict et al., 2018), and are cost-effective alternatives to synthetic fertilizers. Anaerobic digestion of manure reduces adverse impacts of raw manure on the environment such as odor and greenhouse gas emission (Holm-Nielsen et al., 2009) and reduces fecal coliform levels in the manure (Saunders et al., 2012). Ammonium sulfate (AS), the most frequently used type of nitrogen fertilizer for blueberry production (Vargas and Bryla, 2015), is either produced from chemically processed products or anaerobically digested manure (Benedict et al., 2018). Manure-derived AS captures ammonium and directly provides plant-available minerals for crops (Chien et al., 2011), and also overcomes the drawbacks of applying raw manure including the difficulties of transporting and storing and the concerns of affecting air, water, and soil qualities (Yorgey et al., 2014; Benedict et al., 2018). As a result, AS is commonly used in blueberry production, which improves berry yield (Rempel et al., 2004). Though anaerobic digestion of manure reduces pathogens (Yorgey et al., 2014), its efficacy of pathogen reduction varies depending on pathogen type and anaerobic digestion condition (Aitken et al., 2007; Masse et al., 2011). Thus, manure-derived AS could contain pathogens, and there is a need to evaluate the potential impact of its application on microbial safety of produced blueberry.

Blueberry production in northwestern Washington occurs in proximity to dairy production that further increases pathogen contamination risks. As a result, besides pathogen introduction from biological soil amendments, the runoff from dairy farms could increase the potential contamination risk of foodborne pathogens (Doyle and Erickson, 2008). This was highlighted by a recent E. coli O157:H7 outbreak linked to romaine lettuce (FDA, 2018b), where the runoff from adjacent dairy farm was identified as a potential source of E. coli O157:H7. In addition, soil could be contaminated by foodborne pathogens from irrigation water (Steele and Odumeru, 2004) and domestic/ wild animal feces (Gorski et al., 2011). The contaminated soil could further contaminate the fresh produce through aerosols under harsh weather such as strong winds (Baertsch et al., 2007). Furthermore, worker hygiene and sanitation practices during blueberry production play a role in microbial contamination due to their contacts with both soil and crop (Gurtler, 2017). Therefore, examining the prevalence of foodborne pathogens in soil and fruits is critical to ensure pre-harvest food safety.

Currently, there is no information available regarding the potential risk of foodborne pathogen contamination during blueberry production in the field with or without manurederived AS. By analyzing two blueberry production seasons (2017-2018), this study aimed to dynamically evaluate the pre-harvest microbiological safety of blueberry production by monitoring indicator microorganisms, total coliforms and generic E. coli, and the main foodborne pathogens including STEC, Salmonella, and L. monocytogenes in fertilizers, soil, foliar, and blueberry fruit samples.

\section{MATERIALS AND METHODS}

\section{Field Design and Sample Collection}

The experiment was conducted in a 10-year-old 1.25-ha "Draper" blueberry field located in Whatcom County, which is the leading berry production area in Washington (DeVetter et al., 2015) as well as ranked the 38th in the United States for milk production (USDA, 2018). The farm implemented Good Agricultural Practices (GAP) during blueberry production (USDA, 1998). The irrigation water was filtered and treated with chlorine before use. The fences were installed, and the signage was used for exclusion of domestic animals. All workers took food safety training and had access to portable toilets equipped with hand washing stations and hand sanitizer.

The monthly temperature in March, April, May, June, July, and August during 2017-2018 production seasons was 6.4-7.3, 9.6-10.0, 13.1-14.2, 15.4-15.7, $17.5-18.8$, and $17.6-18.1^{\circ} \mathrm{C}$, respectively. The precipitation ranged from 0.00 to $0.48 \mathrm{~cm}$, the wind speed ranged from 2.53 to $3.74 \mathrm{~m} / \mathrm{s}$, and the humidity ranged from 66.62 to $82.96 \%$ during the $2017-2018$ production seasons (Weatherunderground, 2019). Individual blueberry plots measured $22.86 \mathrm{~m} \times 3.05 \mathrm{~m}$ containing one row of blueberry plants irrigated with water using two buried drip lines. Standard dry synthetic fertilizer as control (CON) was supplied by CHS Northwest (Lynden, WA) and applied using a side-discharge fertilizer spreader. Liquid AS, a fertilizer derived from anaerobic digestion of raw manure straight lagoon (Benedict et al., 2018), was applied via $\mathrm{CO}_{2}$ backpack sprayer (Bellspray Inc., Opelousas, LA) at 32 pounds per square inch (PSI). Treatment plots were set up in a completely randomized design (Figure 1). AS was extracted from the anaerobically digested raw manure straight lagoon through ammonia stripping process (Benedict et al., 2018; Frear et al., 2018) by Regenis Corporation of Ferndale (Lynden, WA). AS was either applied 
once for each production season (AS1) or applied as a split application 4 weeks apart (AS2). The total amount of AS applied to each blueberry plot was the same. AS1 and the first portion of AS2 application occurred on the same day to deliver identical total nitrogen at the same rate as CON (based on commercial grower standard). AS was applied directly to soil at the base of the blueberry plants. Physiochemical properties including nutritional information and moisture content of AS and CON are summarized in Table 1. The $\mathrm{pH}$ of fertilizer samples is listed in Table 2 .

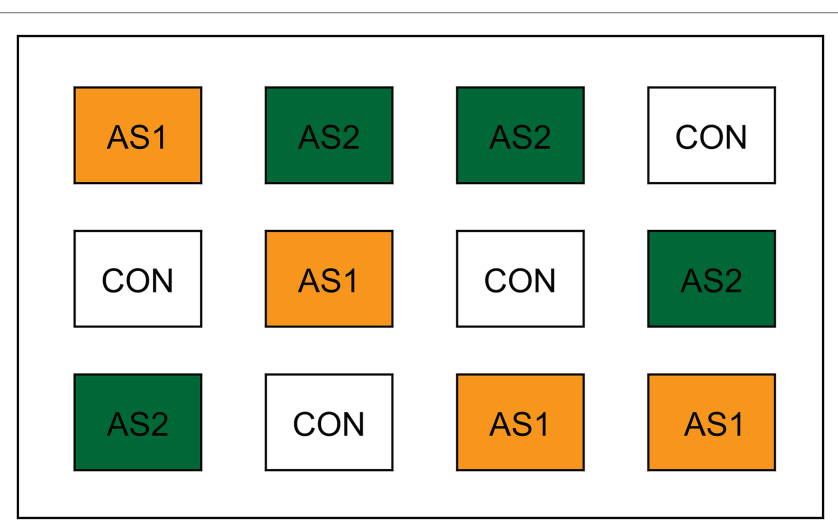

FIGURE 1 | Fertilizer application on the designed plots in 2017-2018 production seasons. CON, standard fertilization; AS1, manure-derived ammonium sulfate; AS2, manure-derived ammonium sulfate applied in split applications.

TABLE 1 | Physiochemical properties of tested fertilizers.

\begin{tabular}{|c|c|c|c|c|c|}
\hline \multirow{2}{*}{$\begin{array}{l}\text { Fertilizer } \\
\text { treatment }\end{array}$} & \multirow[t]{2}{*}{ Moisture (\%) } & \multicolumn{2}{|c|}{ Nitrogen } & \multirow{2}{*}{$\begin{array}{l}\text { Phosphorus } \\
\left(\mathrm{g} \mathrm{P}_{2} \mathrm{O}_{5} / \mathrm{kg}\right)\end{array}$} & \multirow{2}{*}{$\begin{array}{l}\text { Potassium } \\
\left.\text { (g K } \mathrm{K}_{2} \mathrm{O} / \mathrm{kg}\right)\end{array}$} \\
\hline & & $\mathrm{NH}_{4}(\mathrm{~g} / \mathrm{kg})$ & $\begin{array}{c}\text { Total N } \\
(\mathrm{g} / \mathrm{kg})\end{array}$ & & \\
\hline CON & / & 110.00 & 120.00 & 130.00 & 140.00 \\
\hline AS1 & 100.0 & 52.44 & 50.39 & 0.001 & 0.01 \\
\hline AS2 & 100.0 & 52.44 & 50.39 & 0.001 & 0.01 \\
\hline
\end{tabular}

Values were averaged from 12 samples/fertilizer over the 2-year study (6 samples/year, $n=12)$. /, not measured; CON, standard fertilization; AS1, manure-derived ammonium sulfate; AS2, manure-derived ammonium sulfate applied in split applications.

TABLE 2 | pH of fertilizer, soil, foliar, and blueberry fruit samples in 2017-2018.

\begin{tabular}{lcccc}
\hline $\begin{array}{l}\text { Fertilizer } \\
\text { treatment }\end{array}$ & Fertilizer & Soil & Foliar & Fruit \\
\hline CON & $/$ & $4.69 \pm 0.07$ & & \\
AS1 & $1.77 \pm 0.00$ & $4.65 \pm 0.12$ & $6.05 \pm 0.01$ & $3.51 \pm 0.03$ \\
AS2 & $1.77 \pm 0.00$ & $4.75 \pm 0.10$ & & \\
\hline
\end{tabular}

Data are represented as mean $\pm S E M, n=12,6$ and 32 for fertilizer, foliar or fruit and soil, respectively. The $\mathrm{pH}$ of soil was averaged from $\mathrm{pH}$ of soil samples collected at March (pre-fertilizer application), April (post-fertilizer application), June and August of each production season, four samples per sampling points, thus a total of 32 samples. I. not measured; CON, standard fertilization; AS1, manure-derived ammonium sulfate; AS2, manure-derived ammonium sulfate applied in split applications.
The fertilizer products were sampled before applying to soils in late March. For CON fertilizer sampling, 8-10 subsamples ( $\sim 50 \mathrm{~g}$ each) were taken from three depths, and placed in an one liter polyethylene bottle (Nalgene, Thermo Fisher Scientific Inc., Waltham, MA). AS1 and AS2 samples were taken from a 100-gallon liquid container, well mixed before sampling. Soil samples were collected pre- and post-fertilizer application, as well as pre- and post-fruit harvest for both 2017 and 2018 production seasons (Figure 2), because soil could be a pathway for introducing foodborne pathogens to crop from pre-harvest practices and environmental contaminations. Individual soil samples were collected at a depth of $0-5 \mathrm{~cm}$ in the plot by a soil core sampler (2.5 cm diameter) and placed into a Ziploc storage bag (Johnson \& Son, Racine, WI) (EPA, 2014). Each soil sample (400-500 g) composing of 20-25 subsamples ( $20 \mathrm{~g} /$ subsample) was collected in duplicate from each plot. Both foliar and blueberries were collected to investigate the microbiological safety of crop under current pre-harvest practices (Figure 2). Foliar samples $(\sim 100 \mathrm{~g}$ per sample) were randomly collected from the bushes at pre-harvest in duplicate per plot and placed in paper bags. Blueberries were collected in triplicate from each plot with $\sim 100 \mathrm{~g} / \mathrm{sample}$ and placed into a plastic clamshell container to avoid damage (Figure 2). All the collected samples were immediately chilled on ice in an insulated cooler and transported to the Washington State University Food Microbiology laboratory (Pullman, WA) for analysis within 24 h. The $\mathrm{pH}$ of soil, foliar, and blueberry fruit samples was further measured and is summarized in Table 2.

\section{Microbial Indicator Analysis}

Generic E. coli was previously used as an indicator for pathogenic bacterial contamination in field studies (Natvig et al., 2002). Thus, generic E. coli along with total coliforms were analyzed as microbial indicators in this study. Microbial indicator analysis was conducted following FDA's Bacteriological Analytical Manual (BAM) (FDA, 2002) with minor modifications. Total coliforms and generic $E$. coli of soil samples were enumerated by both directly plating and 3-tube most probable number (MPN), while only MPN quantification was used for fertilizer, foliar, and blueberry fruit samples. Each representative sample of $25 \mathrm{~g}$ was homogenized in 225-ml buffered peptone water [BPW, Becton, Dickinson and Company (BD), Sparks, MD]. The well-mixed bacterial suspension was serially diluted and plated onto duplicate plates of CHROMagar ECC (CHROMagar, Paris, FR), followed by incubation at 30 and $44.5^{\circ} \mathrm{C}$ for $24 \mathrm{~h}$ for enumeration of total coliforms and generic E. coli, respectively. For MPN determination, $1 \mathrm{ml}$ of the above bacterial suspension was transferred to three tubes containing $9 \mathrm{ml}$ of lauryl sulfate broth [LST, Hardy Diagnostics (HD), Santa Maria, CA] and incubated at $35^{\circ} \mathrm{C}$ for $24-48 \mathrm{~h}$. Positive tubes that showed both turbidity and gas production were further confirmed in brilliant green lactose bile (BGLB, HD) broth and E. coli broth with 4-methylumbelliferyl- $\beta$-D-glucuronide (EC + MUG, HD) for total coliforms and generic E. coli, respectively. BGLB tubes were incubated at $35^{\circ} \mathrm{C}$ for $24-48 \mathrm{~h}$, and tubes that showed turbidity and gas production were considered coliform positive. $\mathrm{EC}+\mathrm{MUG}$ tubes were incubated at $44.5^{\circ} \mathrm{C}$ for $48 \mathrm{~h}$, and tubes 
Soil sampling

○ 4 plots/treatment, 2 samples/plot

- 20-25 subsamples/sample, $20 \mathrm{~g} /$ subsample

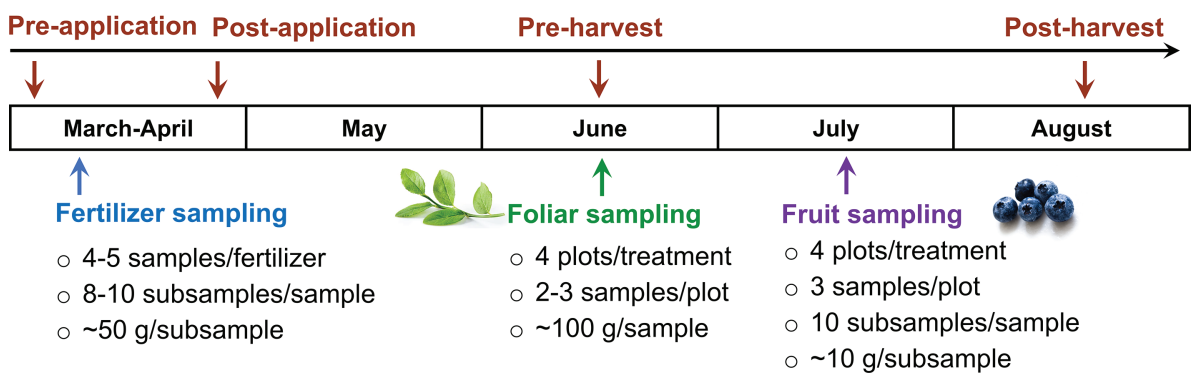

FIGURE 2 | Microbiological sample collection plan in 2017-2018 production seasons.

that showed turbidity, gas production and fluorescent under a long-wave UV lamp were considered generic E. coli positive.

\section{Pathogen Detection and Confirmation Shiga Toxin-Producing Escherichia coli}

Presumptive STEC were isolated following BAM method (Feng et al., 2011). Each representative sample of $25 \mathrm{~g}$ was homogenized in modified BPW with $0.1 \%(\mathrm{w} / \mathrm{v})$ pyruvate (mBPWp, Amresco, Solon, $\mathrm{OH}$ ), incubated at $35^{\circ} \mathrm{C}$ for $5 \mathrm{~h}$, then supplemented with $10 \mathrm{mg} / \mathrm{l}$ acriflavine (TCI, Portland, OR), $10 \mathrm{mg} / \mathrm{l}$ cefsulodin (Sigma-Aldrich, St. Louis, MO), and $8 \mathrm{mg} / \mathrm{l}$ vancomycin (SigmaAldrich), mixed and incubated at $42^{\circ} \mathrm{C}$ for additional $18-24 \mathrm{~h}$. The overnight enrichment cultures were serially diluted and plated onto CHROMagar STEC (CHROMagar) and confirmed by PCR assay (Feng and Monday, 2000). In addition, the overnight enrichment cultures were used to extract DNA and subject to multiplex PCR assay for the detection of STEC per the BAM method by targeting uidA with stx 1 and/or stx 2 for STEC per previously published methods (Feng et al., 2011).

\section{Salmonella}

The isolation of Salmonella spp. was conducted per the BAM method (FDA, 2011). Each representative sample of $25 \mathrm{~g}$ was homogenized in $\mathrm{BPW}$ and enriched at $35^{\circ} \mathrm{C}$ for $24 \mathrm{~h}$. One milliliter of the overnight culture was sub-cultured to $10 \mathrm{ml}$ of tetrathionate broth (TT, BD) supplemented with $2 \%$ iodine-iodide solution (HD) and incubated at $35^{\circ} \mathrm{C}$ for $24 \mathrm{~h}$, or $0.1 \mathrm{ml}$ of the overnight culture was sub-cultured to $10 \mathrm{ml}$ of RappaportVassiliadis broth (RV, BD) and incubated at $42^{\circ} \mathrm{C}$ for $24 \mathrm{~h}$. The resulting enrichment culture was streaked onto xylose lysine deoxycholate (XLD, HD), bismuth sulfite (BS, HD), hektoen enteric (HE, HD) and CHROMagar Salmonella (CHROMagar) plates and incubated at $37^{\circ} \mathrm{C}$ for $24-48 \mathrm{~h}$ to discriminate Salmonella. Presumptive colonies were defined as the pink colonies with or without black centers on XLD, the brown, gray, or black colonies with or without metallic sheens on BS, the blue-green colonies with or without black centers on $\mathrm{HE}$, and the mauve colonies on CHROMagar Salmonella plate. The presumptive colonies were further confirmed by Salmonella Latex Test (Oxoid Ltd., Hants, UK) and by PCR targeting Salmonella invasive gene invA
(Rahn et al., 1992). Salmonella positive samples were further enumerated by the modified 3-tube MPN method (Fravalo et al., 2003) and interpreted according to BAM with the detection limit of $3 \mathrm{MPN} / \mathrm{g}$ (FDA, 2010). The enumeration test was performed a day after the confirmation of the presence of Salmonella.

\section{Listeria monocytogenes}

To isolate L. monocytogenes, 25 grams of respective samples were suspended in $225 \mathrm{ml}$ of buffered Listeria enrichment broth (BLEB, $\mathrm{BD})$, incubated for $4 \mathrm{~h}$ at $30^{\circ} \mathrm{C}$, then supplemented with acriflavine (TCI), nalidixic acid (Sigma-Aldrich), and cycloheximide (Amresco) for an additional selective enrichment at $30^{\circ} \mathrm{C}$ for $24-48 \mathrm{~h}$. The enrichment culture was streaked onto both Modified Oxford agar (MOX, BD) and CHROMagar Listeria (CHROMagar) plates and incubated at $37^{\circ} \mathrm{C}$ for $24-48 \mathrm{~h}$. Presumptive colonies were defined as smooth, round, turquoise colonies $1-1.5 \mathrm{~mm}$ in diameter surrounded by an opaque white halo on MOX, and blue colonies with white halo on CHROMagar Listeria plates, and were confirmed by PCR targeting the different region of the invasion-associated secreted endopeptidase (iap) gene (FDA, 2017).

\section{Statistical Analysis}

The total coliforms and generic E. coli in soil samples per treatment were analyzed with one-way analysis of variance (ANOVA) and least significant difference (LSD) multiplecomparison test using IBM SPSS 19.0 (Chicago, IL). Results were considered significant at $p \leq 0.05$. Data were reported as mean $\pm \mathrm{SEM}$ (standard error mean).

\section{RESULTS}

\section{Enumeration of Indicator Microorganism in Fertilizer, Soil, Foliar, and Blueberry Samples}

Total coliforms and generic E. coli were analyzed to represent the fecal contamination potential of the tested samples (Lonigro et al., 2016). In both 2017 and 2018 production seasons, total coliforms or generic E. coli were not detected in any fertilizer, 
foliar, and blueberry fruit samples by the MPN method with the detection limit of $3 \mathrm{MPN} / \mathrm{g}$ (data not shown). The population of total coliforms in soils was $\sim 3.5 \log _{10} \mathrm{CFU} / \mathrm{g}$ and relatively stable throughout the 2017 production season regardless of fertilizer application (Figure 3A). Similar phenomenon was
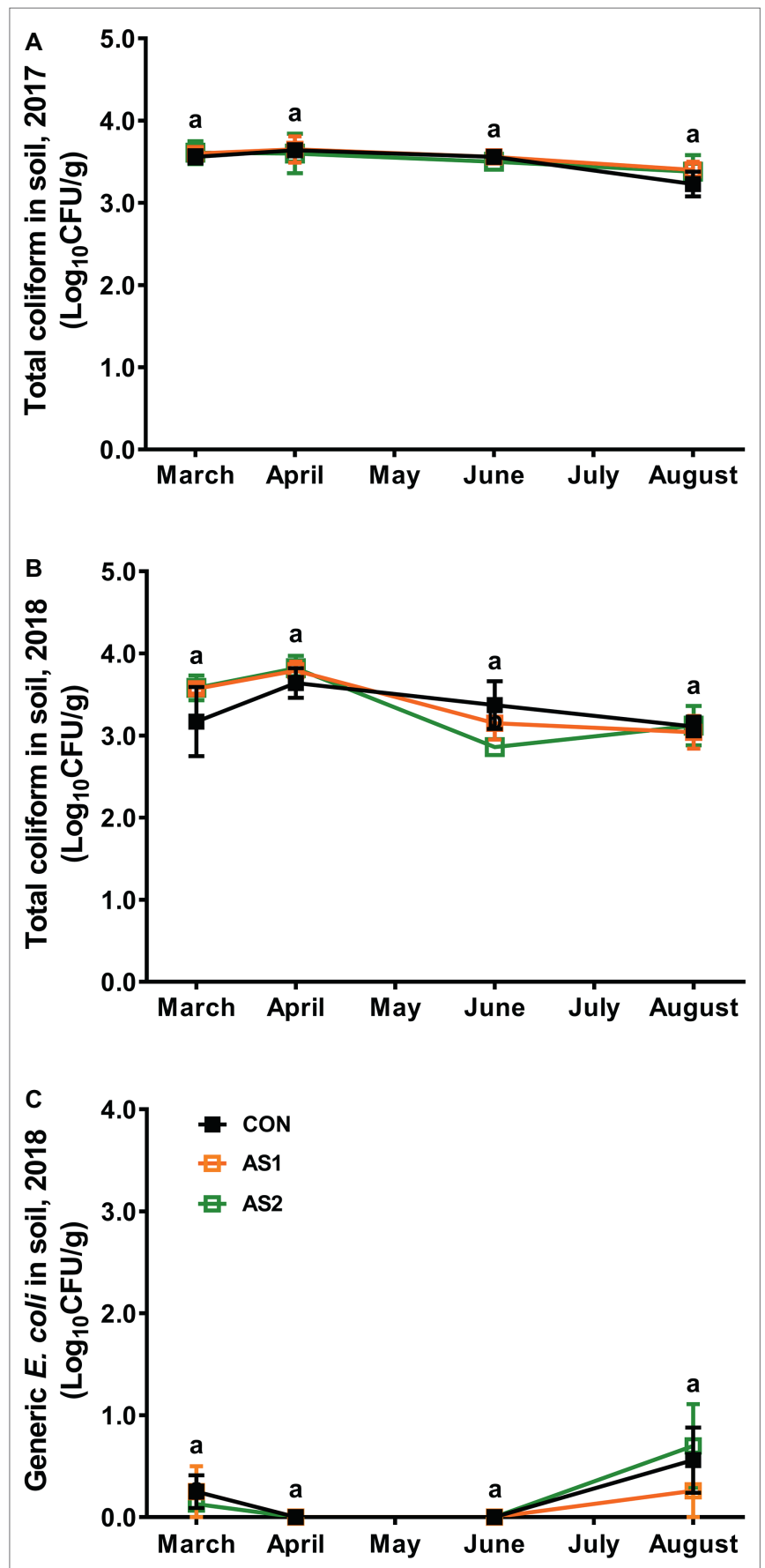

FIGURE 3 | Abundance of total coliforms in soil samples collected from the blueberry field during 2017-2018 production seasons. (A) Total coliform 2017; (B) Total coliform 2018; (C) Generic E. coli 2018. $n=4$. Means at each sampling point without common letter differ significantly $(p<0.05)$. CON, standard fertilization; AS1, manure-derived ammonium sulfate; AS2, manure-derived ammonium sulfate applied in split applications. observed in the 2018 production season (Figure 3B). Generic E. coli stayed at very low levels of $0.13-0.25 \log _{10} \mathrm{CFU} / \mathrm{g}$ throughout the 2018 production season regardless of fertilizer application/practices (Figure 3C).

\section{Detection of Pathogens in Fertilizer, Soil, Foliar, and Blueberry Samples}

STEC were not detected in fertilizer, soil, foliar, or blueberry fruit samples throughout 2017-2018 production seasons either by multiplex PCR or direct plating method followed by PCR confirmation of all the presumptive STEC colonies (1-10 colonies per plate, targeting Shiga toxin genes stx 1 and stx2 with the detection limit of $1 \mathrm{CFU} / \mathrm{g}$ ) (Table 3; Feng and Monday, 2000). In 2017, Salmonella were not detected in fertilizer and soil samples collected at all sampling stages throughout the production season, nor were they detected in foliar or blueberry fruit samples regardless of fertilizer application (Table 4). In the 2018 cropping season, Salmonella were not detected in fertilizer samples but were detected in all soil samples collected pre-fertilizer application and some of those collected post-fertilizer application (Table 4). The level of Salmonella contamination ranged from 0.48 to $1.04 \log _{10} \mathrm{MPN} / \mathrm{g}$ in soil (Table 5). Salmonella were not detected in soil samples collected before or after fruit harvest, nor were they detected in foliar or blueberry fruit samples (Table 4). In both production seasons, $L$. monocytogenes were not detected in fertilizer, soil, foliar, or blueberry fruit samples regardless of fertilizer application practices (Table 6).

\section{DISCUSSION}

Fresh produce is recently recognized as a main foodborne source for STEC, Salmonella, and L. monocytogenes (Luna and Mody, 2010; CDC, 2012; Miller et al., 2013). Cattle are the main reservoir of STEC, Salmonella, and L. monocytogenes (Heredia and Garcia, 2018). STEC can be shed in manure, transferred to soil, and persist for an extended period (Fremaux et al., 2008). The manure-derived AS might carry pathogens originated from gastrointestinal tract of healthy animals (Aitken et al., 2007). Once applied, manure-derived fertilizers further transfer pathogens to fresh produce, resulting in deadly outbreaks (CDC, 2018b). AS application does not require an interval time by the Produce Safety Rule under the Food Safety Modernization Act (FSMA) (FDA, 2018a), which might increase the chance of contamination of produce. Up to now, little is known about the microbial safety of blueberry produced with manure-derived AS application. We found that AS derived from anaerobic digestion of raw dairy manure was absent of indicator and pathogenic microorganisms, indicating no safety concern of using manure-derived AS for soil amendment in blueberry field. Split application of nitrogen fertilizer in blueberry production is a common agricultural practice, which results in higher yields than that of single application (Hanson and Retamales, 1992; Rempel et al., 2004). Our data indicated 
TABLE 3 I STEC analyses in fertilizer, soil, foliar, and blueberry fruit samples in 2017-2018.

\begin{tabular}{|c|c|c|c|c|c|c|c|}
\hline \multirow{3}{*}{ Treatment } & \multirow{3}{*}{ Fertilizer } & \multicolumn{4}{|c|}{ Soil } & \multirow{3}{*}{ Foliar } & \multirow{3}{*}{ Fruit } \\
\hline & & \multicolumn{2}{|c|}{ March-April } & \multirow{2}{*}{ June } & \multirow{2}{*}{ August } & & \\
\hline & & Pre & Post & & & & \\
\hline CON & $0 / 5^{a}$ & $0 / 4$ & $0 / 4$ & $0 / 4$ & $0 / 4$ & $0 / 4$ & $0 / 4$ \\
\hline AS1 & $0 / 5$ & $0 / 4$ & $0 / 4$ & $0 / 4$ & $0 / 4$ & $0 / 4$ & $0 / 4$ \\
\hline AS2 & $0 / 5$ & $0 / 4$ & $0 / 4$ & $0 / 4$ & $0 / 4$ & $0 / 4$ & $0 / 4$ \\
\hline
\end{tabular}

aPositive samples/total samples for each treatment. 2017 and 2018 production seasons with the same result was only reported once. Shiga toxin-producing E. coli (STEC) was detected by CHROMagar STEC plates and confirmed by PCR or multiplex PCR assay. CON, standard fertilization; AS1, ammonium sulfate; AS2, ammonium sulfate applied in split applications; Pre/Post, soils were sampled pre-application/post-application of fertilizers in late March and early April; June, soils were sampled in June before fruit harvest; August, soils were sampled in August after fruit harvest.

TABLE 4 | Detection of Salmonella in fertilizer, soil, foliar, and blueberry fruit samples in 2017-2018.

Soil

\begin{tabular}{|c|c|c|c|c|c|c|c|}
\hline \multirow[t]{2}{*}{ Treatment } & \multirow[t]{2}{*}{ Fertilizer } & \multicolumn{2}{|c|}{ March-April } & \multirow{2}{*}{ June } & \multirow{2}{*}{ August } & \multirow[t]{2}{*}{ Foliar } & \multirow[t]{2}{*}{ Frui } \\
\hline & & Pre & Post & & & & \\
\hline CON & $0 / 4^{a}$ & $0 / 8 \mid \mathbf{8} / 8^{b}$ & $0 / 8 \mid 1 / 8$ & $0 / 8$ & $0 / 8$ & $0 / 12$ & $0 / 12$ \\
\hline AS1 & $0 / 4$ & 0/8|8/8 & $0 / 8 \mid 2 / 8$ & $0 / 8$ & $0 / 8$ & $0 / 12$ & $0 / 12$ \\
\hline AS2 & $0 / 4$ & 0/8|8/8 & $0 / 8 \mid 2 / 8$ & $0 / 8$ & $0 / 8$ & $0 / 12$ & $0 / 12$ \\
\hline
\end{tabular}

aPositive samples/total samples for each treatment; 2017 and 2018 production seasons with the same result was only reported once.

${ }^{b}$ Positive samples/total samples in 2017|Positive samples/total samples in 2018; the positive results were confirmed by Latex Salmonella and PCR detection of invA gene; CON, standard fertilization; AS1, manure-derived ammonium sulfate; AS2, manure-derived ammonium sulfate applied in split applications; Pre/Post, soils were sampled pre-application/ post-application of fertilizers in late March and early April; June, soils were sampled in June before fruit harvest; August, soils were sampled in August after fruit harvest.

TABLE 5 | Most probable number determination of Salmonella in soil samples collected during 2018 production season.

\begin{tabular}{|c|c|c|c|c|}
\hline \multirow{2}{*}{ Treatment } & \multicolumn{2}{|c|}{ March-April } & \multirow[t]{2}{*}{ June } & \multirow[t]{2}{*}{ Augus } \\
\hline & Pre & Post & & \\
\hline CON & $<1.04 \pm 0.37^{a}$ & $<0.52 \pm 0.05$ & / & / \\
\hline AS1 & $<0.48 \pm 0.00$ & $<0.48 \pm 0.00$ & / & / \\
\hline AS2 & $<0.67 \pm 0.13$ & $<0.49 \pm 0.01$ & / & l \\
\hline
\end{tabular}

aMost probable number, $\log _{10}$ MPN/g, Mean \pm SEM, $n=8$; /, not enumerated; CON, standard fertilization; AS1, manure-derived ammonium sulfate; AS2, manure-derived ammonium sulfate applied in split applications; Pre/Post, soils were sampled pre-application/post-application of fertilizers in late March and early April; June, soils were sampled in June before fruit harvest; August, soils were sampled in August after fruit harvest.

that the application method of manure-derived AS, single or split application, had no effect on the microbial safety of blueberry production.

Total coliforms and generic E. coli were previously used as hygiene indicators in soil and fresh produce (Natvig et al., 2002; Denis et al., 2016; Lonigro et al., 2016). Total coliform level in soils from the blueberry field remained relatively stable over seasons regardless of fertilizer application/practice, which was lower than that of soils of a parallel raspberry study (Sheng et al., 2019). This could probably be due to different production environment and/or agriculture practices. Generic E. coli remained at very low counts throughout the 2018 production season regardless of fertilizer application, which was consistent with a recent study in soils from a raspberry field (Sheng et al., 2019). Similarly, application of compost did not affect E. coli abundance in soils (Larney et al., 2003). Amending soils with anaerobically digested dairy manure did not affect the die-off rate of E. coli in soils (Saunders et al., 2012). Generic E. coli levels of post-fruit harvest soil samples were slightly increased, which was possibly due to the increased human activities and/or the environmental temperature in the late production season. Consistently, the transient residence of generic E. coli in soils was reported to be related to soil moisture and environmental temperature (Lang et al., 2007). In this study, total coliforms or generic E. coli were not associated with the presence of Salmonella in soils, suggesting they might not be appropriate indicator microorganisms in a berry production environment. Similar to our findings, the total coliform level of soil was not correlated with Salmonella presented in soils cultivating raspberry (Sheng et al., 2019) or lettuce (Holvoet et al., 2014). Generic E. coli was not associated with the presence of Salmonella in raspberry (Sheng et al., 2019) or leafy green produce field (Benjamin et al., 2013).

E. coli O157: H7 and non-O157 STEC have increasingly been implicated in deadly fresh produce outbreaks (CDC, 2017, 2018b). STEC were not detected in soil samples with different fertilizer applications using both traditional culture-based method and multiplex PCR method, indicating that blueberry production 
TABLE 6 | Listeria monocytogenes analyses in fertilizer, soil, foliar, and blueberry fruit samples in 2017-2018.

\begin{tabular}{|c|c|c|c|c|c|c|c|}
\hline \multirow{3}{*}{ Treatment } & \multirow{3}{*}{ Fertilizer } & \multicolumn{4}{|c|}{ Soil } & \multirow{3}{*}{ Foliar } & \multirow{3}{*}{ Frui } \\
\hline & & \multicolumn{2}{|c|}{ March-April } & \multirow{2}{*}{ June } & \multirow{2}{*}{ August } & & \\
\hline & & Pre & Post & & & & \\
\hline CON & $0 / 5^{a}$ & $0 / 4$ & $0 / 4$ & $0 / 4$ & $0 / 4$ & $0 / 4$ & $0 / 4$ \\
\hline AS1 & $0 / 5$ & $0 / 4$ & $0 / 4$ & $0 / 4$ & $0 / 4$ & $0 / 4$ & $0 / 4$ \\
\hline AS2 & $0 / 5$ & $0 / 4$ & $0 / 4$ & $0 / 4$ & $0 / 4$ & $0 / 4$ & $0 / 4$ \\
\hline
\end{tabular}

aPositive samples/total samples for each treatment. L. monocytogenes was detected by both Modified Oxford agar and CHROMagar Listeria plates. 2017 and 2018 production seasons with the same result was only reported once. CON, standard fertilization; AS1, ammonium sulfate; AS2, ammonium sulfate applied in split applications; Pre/Post, soils were sampled pre-application/post-application of fertilizers in late March and early April; June, soils were sampled in June before fruit harvest; August, soils were sampled in August after fruit harvest.

using manure-derived AS fertilizer did not pose a STEC risk. This was consistent with a recent study on raspberry field, where STEC was not detected in soil amended with various manure-based fertilizers (Sheng et al., 2019). Anaerobic digestion facilitates E. coli O157:H7 inactivation in dairy manure, especially at a high-temperature condition (Aitken et al., 2007). The acidic soil $\mathrm{pH}$ of blueberry fields might also contribute to inactivation of STEC, because the survival of STEC in soils was impaired by the acidic environment (Erickson et al., 2014).

Salmonella is stable in a dry environment and subsequent thermal treatment (Tsai et al., 2019) and develops resistance to a wide range of antibiotics (Sobsey et al., 2006). Salmonella has frequently been involved in fresh produce outbreaks (Miller et al., 2013; CDC, 2018a). In the 2018 cropping season, Salmonella was detected in early season soil samples regardless of fertilizer application. Similarly, Salmonella were not detected in anaerobically digested manure but were isolated from soils after anaerobically digested manure application (Goberna et al., 2011; Sheng et al., 2019). The 2.6 and $2.2 \%$ of soil samples collected from produce fields in California and New York State, respectively, were positive of Salmonella (Gorski et al., 2011; Strawn et al., 2013). The detection of Salmonella in blueberry field could be due to precipitation (Gorski et al., 2011), wild animal feces (Gorski et al., 2011), irrigation water (Steele and Odumeru, 2004), farm animal activity (Nottingham and Urselmann, 1961), and others. The precipitation in Whatcom County, Washington, was higher during pre- and post-fertilizer application in March-April 2018 compared to that in late production seasons, which might contribute to the transient presence of Salmonella in early season soil samples. The exact reason for the reduced prevalence of Salmonella in post-fertilizer soil samples was unknown. However, this could be due to additional die-off with time and the interaction of Salmonella with fertilizers and soils. Indeed, soil temperature, $\mathrm{pH}$ and moisture content as well as soil microbial community could affect the survival of Salmonella in soils and result in the dynamic change of Salmonella (Bradford et al., 2013). To maximize the recovery and detection of Salmonella, different selective media were used in this study, due to the different performance of the existing selected selective media (Pal and Marshall, 2009).
L. monocytogenes poses a unique challenge to fresh produce due to its high mortality rate and ubiquitous nature in environment (Weis and Seeliger, 1975; CDC, 2012). L. monocytogenes are commonly isolated from the feces of dairy cattle (Heredia and Garcia, 2018) and can survive in manure for up to 6 months (Nicholson et al., 2005). In this study, L. monocytogenes were not detected in soil samples amended with CON or AS. In support of our finding, L. monocytogenes were not detected in soils that were amended with various manurebased fertilizers culturing raspberry (Sheng et al., 2019) or leafy green (Rahube et al., 2014).

Consistent with soil microbial results, neither indicator microorganisms nor pathogenic bacteria were detected from foliar or blueberry fruit samples collected during both cropping seasons regardless of fertilizer treatments. Similar to our findings, pathogenic bacteria or generic $E$. coli were not detected in $\sim 500$ blueberries samples according to a 4 -year survey (Denis et al., 2016). The most common type of blueberry cultivated in Washington State are highbush blueberries (Vaccinium corymbosum) at 6-10 feet tall (Strik et al., 2014), where blueberries are less likely to directly contact with soils at growing season compared to lowbush blueberries. As a result, blueberry fruits are less likely to be contaminated during production compared to produce such as lettuce grown close to soil (Murphy et al., 2016). In addition, the low pH of blueberry fruits might provide another hurdle against foodborne pathogens (Nguyen et al., 2014).

\section{CONCLUSION}

This 2-year field study demonstrated that, under good agricultural practices, blueberries produced in fields with or without manurederived fertilizer AS had little food safety concern. STEC and L. monocytogenes were all below the detection limit in all samples collected during both production seasons. Salmonella were below the detection limit in all samples except early season soil samples collected in 2018 production season. Additionally, the total coliforms in soil samples remained stable throughout the production seasons and were not detectable in fruit samples. This study provides valuable information for the blueberry industry 
regarding microbiological safety concern of close proximity to dairy production and the use of manure-derived fertilizers.

\section{DATA AVAILABILITY STATEMENT}

All datasets generated for this study are included in the article.

\section{AUTHOR CONTRIBUTIONS}

XS, LS, and YS performed the experiment. M-JZ, CK, and CB designed the experiment. XS and M-JZ wrote the manuscript. $\mathrm{CB}$ and ES helped with sample collection. M-JZ, CB, CK, LS, and $\mathrm{YZ}$ revised the manuscript.

\section{REFERENCES}

Aitken, M. D., Sobsey, M. D., Van Abel, N. A., Blauth, K. E., Singleton, D. R., Crunk, P. L., et al. (2007). Inactivation of Escherichia coli O157:H7 during thermophilic anaerobic digestion of manure from dairy cattle. Water Res. 41, 1659-1666. doi: 10.1016/j.watres.2007.01.034

Baertsch, C., Paez-Rubio, T., Viau, E., and Peccia, J. (2007). Source tracking aerosols released from land-applied class B biosolids during high-wind events. Appl. Environ. Microbiol. 73, 4522-4531. doi: 10.1128/AEM.02387-06

Benedict, C., Harrison, J., Hall, S. A., and Yorgey, G. (2018). Nutrient recovery: products from dairy manure to improve soil fertility. WSU extension: FS305E. Available at: http://cru.cahe.wsu.edu/CEPublications/FS305E/FS305E.pdf (Accessed September 20, 2019).

Benjamin, L., Atwill, E. R., Jay-Russell, M., Cooley, M., Carychao, D., Gorski, L., et al. (2013). Occurrence of generic Escherichia coli, E. coli O157 and Salmonella spp. in water and sediment from leafy green produce farms and streams on the Central California coast. Int. J. Food Microbiol. 165, 65-76. doi: 10.1016/j.ijfoodmicro.2013.04.003

Bradford, S. A., Morales, V. L., Zhang, W., Harvey, R. W., Packman, A. I., Mohanram, A., et al. (2013). Transport and fate of microbial pathogens in agricultural settings. Crit. Rev. Environ. Sci. Technol. 43, 775-893. doi: 10.1080/10643389.2012.710449

CDC (2012). Multistate outbreak of Listeriosis linked to whole cantaloupes from jensen farms, Colorado (final update). Available at: https://www. cdc.gov/listeria/outbreaks/cantaloupes-jensen-farms/index.html (Accessed September 20, 2019).

CDC (2017). Multistate outbreak of Shiga toxin-producing Escherichia coli O157:H7 infections linked to leafy greens (Final Update). Available at: https:// www.cdc.gov/ecoli/2017/o157h7-12-17/index.html (Accessed September 20, 2019).

CDC (2018a). Multistate outbreak of Salmonella Adelaide infections linked to pre-cut melon (Final Update). Available at: https://www.cdc.gov/salmonella/ adelaide-06-18/index.html (Accessed September 20, 2019).

CDC (2018b). Multistate outbreak of shiga toxin-producing Escherichia coli O157:H7 infections linked to leafy greens (final update). Available at: https:// www.cdc.gov/ecoli/2017/o157h7-12-17/index.html (Accessed September 20, 2019).

Chien, S. H., Gearhart, M. M., and Villagarcia, S. (2011). Comparison of ammonium sulfate with other nitrogen and sulfur fertilizers in increasing crop production and minimizing environmental impact: a review. Soil Sci. 176, 327-335. doi: 10.1097/SS.0b013e31821f0816

CSPI (2009). The ten riskiest foods regulated by the U.S. food and drug administration. Available at: https://cspinet.org/sites/default/files/attachment/ cspi_top_10_fda.pdf (Accessed September 20, 2019).

Denis, N., Zhang, H., Leroux, A., Trudel, R., and Bietlot, H. (2016). Prevalence and trends of bacterial contamination in fresh fruits and vegetables sold at retail in Canada. Food Control 67, 225-234. doi: 10.1016/j.foodcont.2016.02.047

\section{FUNDING}

This research was funded by USDA-NRCS (\#693A7516020) and Washington State Departmental of Agriculture (WSDA) (K1811).

\section{ACKNOWLEDGMENTS}

The authors would like to express their gratitude to Curt Maberry Farm for their generous support in conducting this study. They thank Beth Chisholm, Jessica Shaw, and Kolten Kirkendoll for sample collection for microbial analysis, and Dr. Xia Song, Dr. Yang He, and Oscar R. Ulloa for their assistance in soil sample process for microbial analysis.

DeVetter, L. W., Granatstein, D., Kirby, E., and Brady, M. (2015). Opportunities and challenges of organic highbush blueberry production in Washington state. HortTechnology 25, 796-804. doi: 10.21273/HORTTECH.25.6.796

Doyle, M. P., and Erickson, M. C. (2008). Summer meeting 2007 - the problems with fresh produce: an overview. J. Appl. Microbiol. 105, 317-330. doi: 10.1111/j.1365-2672.2008.03746.x

EPA (2014). USEPA/USGS sample collection protocol for bacterial pathogens in surface soil. Available at: https://cfpub.epa.gov/si/si_public_record_report cfm?dirEntryId=285571\&Lab=NHSRC\&fed_org_id=1253\&subject=Homeland+ Security+Research\&view $=$ desc\&sortBy $=$ pubDateYear\&count $=25 \&$ showCriteria $=$ $1 \&$ searchall=biological+and+soil\&submit=Search (Accessed September 20, 2019).

Erickson, M. C., Habteselassie, M. Y., Liao, J., Webb, C. C., Mantripragada, V., Davey, L. E., et al. (2014). Examination of factors for use as potential predictors of human enteric pathogen survival in soil. J. Appl. Microbiol. 116, 335-349. doi: 10.1111/jam.12373

Evans, E. A., and Ballen, F. H. (2014). An overview of US blueberry production, trade, and consumption, with special reference to Florida. University of Florida, IFAS, Extension, FE952. Available at: https://edis.ifas.ufl.edu/pdffiles/ FE/FE95200.pdf (Accessed September 20, 2019).

FDA (1998). Frozen blueberries recalled due to Listeria monocytogenes contamination. FDA Enforcement Rep. 98-52.

FDA (2002). BAM protocol: Enumeration of Eschierchia coli and the coliform bacteria. Available at: https://www.fda.gov/Food/FoodScienceResearch/ LaboratoryMethods/ucm064948.htm (Accessed September 20, 2019).

FDA (2010). BAM appendix 2: most probable number from serial dilutions. Available at: https://www.fda.gov/Food/FoodScienceResearch/LaboratoryMethods/ ucm109656.htm (Accessed September 20, 2019).

FDA (2011). BAM protocol: Salmonella. Chapter 5. Available at: https://www. fda.gov/Food/FoodScienceResearch/LaboratoryMethods/ucm070149.htm (Accessed September 20, 2019).

FDA (2017). BAM protocol: detection and enumeration of Listeria monocytogenes. Available at: https://www.fda.gov/Food/FoodScienceResearch/LaboratoryMethods/ ucm071400.htm (Accessed September 20, 2019).

FDA (2018a). Biological soil amendments of animal origin and human waste, 21 C.F.R. $\$ 112$. (Subpart F). Available at: https://www.accessdata.fda.gov/ scripts/cdrh/cfdocs/cfCFR/CFRSearch.cfm?CFRPart=112\&showFR=1\&subpar tNode=21:2.0.1.1.12.6 (Accessed September 20, 2019).

FDA (2018b). Environmental assessment of factors potentially contributing to the contamination of romaine lettuce implicated in a multistate outbreak of E. coli O157:H7. Available at: https://www.fda.gov/food/outbreaksfoodborne-illness/environmental-assessment-factors-potentiallycontributing-contamination-romaine-lettuce-implicated (Accessed November 22, 2019).

FDA (2019a). Alma pak voluntarily recalls frozen blackberries due to possible health risk of norovirus. Available at: https://www.fda.gov/safety/recallsmarket-withdrawals-safety-alerts/alma-pak-voluntarily-recalls-frozenblackberries-due-possible-health-risk-norovirus (Accessed September 20, 2019).

FDA (2019b). Public health alert concerning hepatitis A virus contamination of kroger brand frozen blackberries and costco kirkland signature brand three 
berry blend. Available at: https://www.fda.gov/food/alerts-advisories-safetyinformation/public-health-alert-concerning-hepatitis-virus-contaminationkroger-brand-frozen-blackberries-and (Accessed September 20, 2019).

Feng, P., and Monday, S. R. (2000). Multiplex PCR for detection of trait and virulence factors in enterohemorrhagic Escherichia coli serotypes. Mol. Cell. Probes 14, 333-337. doi: 10.1006/mcpr.2000.0323

Feng, P., Weagant, S. D., and Jinneman, K. (2011). Bacteriological analytical manual, chapter 4A, diarrheagenic Escherichia coli. Available at: https://www. fda.gov/food/foodscienceresearch/laboratorymethods/ucm070080.htm (Accessed September 20, 2019).

Fravalo, P., Hascoet, Y., Le Fellic, M., Queguiner, S., Petton, J., and Salvat, G. (2003). Convenient method for rapid and quantitative assessment of Salmonella enterica contamination: the mini-MSRV MPN technique. J. Rapid Methods Autom. Microbiol. 11, 81-88. doi: 10.1111/j.1745-4581.2003.tb00031.x

Frear, C., Ma, J., and Yorgey, G., (2018). Approaches to nutrient recovery from dairy manure. Available at: http://pubs.cahnrs.wsu.edu/publications/pubs/ em112e/?p-page $=2$ (Accessed November 22, 2019).

Fremaux, B., Prigent-Combaret, C., Delignette-Muller, M. L., Mallen, B., Dothal, M., Gleizal, A., et al. (2008). Persistence of Shiga toxin-producing Escherichia coli $\mathrm{O} 26$ in various manure-amended soil types. J. Appl. Microbiol. 104, 296-304. doi: 10.1111/j.1365-2672.2007.03532.x

Goberna, M., Podmirseg, S. M., Waldhuber, S., Knapp, B. A., Garcia, C., and Insam, H. (2011). Pathogenic bacteria and mineral $\mathrm{N}$ in soils following the land spreading of biogas digestates and fresh manure. Appl. Soil Ecol. 49, 18-25. doi: 10.1016/j.apsoil.2011.07.007

Gorski, L., Parker, C. T., Liang, A., Cooley, M. B., Jay-Russell, M. T., Gordus, A. G., et al. (2011). Prevalence, distribution, and diversity of Salmonella enterica in a major produce region of California. Appl. Environ. Microbiol. 77, 2734-2748. doi: 10.1128/AEM.02321-10

Gurtler, J. B. (2017). Pathogen decontamination of food crop soil: a review. J. Food Prot. 80, 1461-1470. doi: 10.4315/0362-028X.JFP-17-040

Hanson, E. J., and Retamales, J. B. (1992). Effect of nitrogen source and timing on highbush blueberry performance. HortScience 27, 1265-1267. doi: 10.21273/ HORTSCI.27.12.1265

Heredia, N., and Garcia, S. (2018). Animals as sources of food-borne pathogens: a review. Anim. Nutr. 4, 250-255. doi: 10.1016/j.aninu.2018.04.006

Holm-Nielsen, J. B., Al Seadi, T., and Oleskowicz-Popiel, P. (2009). The future of anaerobic digestion and biogas utilization. Bioresour. Technol. 100, 5478-5484. doi: 10.1016/j.biortech.2008.12.046

Holvoet, K., Sampers, I., Seynnaeve, M., and Uyttendaele, M. (2014). Relationships among hygiene indicators and enteric pathogens in irrigation water, soil and lettuce and the impact of climatic conditions on contamination in the lettuce primary production. Int. J. Food Microbiol. 171, 21-31. doi: 10.1016/j. ijfoodmicro.2013.11.009

Lang, N. L., Bellett-Travers, M. D., and Smith, S. R. (2007). Field investigations on the survival of Escherichia coli and presence of other enteric microrganisms in biosolids-amended agricultural soil. J. Appl. Microbiol. 103, 1868-1882. doi: $10.1111 /$ j.1365-2672.2007.03489.x

Larney, F. J., Yanke, L. J., Miller, J. J., and Mcallister, T. A. (2003). Fate of coliform bacteria in composted beef cattle feedlot manure. J. Environ. Qual. 32, 1508-1515. doi: 10.2134/jeq2003.1508

Larsen, L. (2018). Europe's best field berry mixes recalled for possible Salmonella. Food poisoning Bulletin. Available at: https:/foodpoisoningbulletin.com/2018/ europes-best-field-berry-mixes-recalled-for-possible-salmonella/ (Accessed September 20, 2019).

Lonigro, A., Rubino, P., Lacasella, V., and Montemurro, N. (2016). Faecal pollution on vegetables and soil drip irrigated with treated municipal wastewaters. Agric. Water Manage. 174, 66-73. doi: 10.1016/j.agwat.2016.02.001

Luna, R. E., and Mody, R. (2010). Non-O157 shiga toxin-producing E. coli (STEC) outbreaks, United States. Available at: https://blogs.cdc.gov/ publichealthmatters/files/2010/05/nono157stec_obs_052110.pdf (Accessed September 20, 2019).

Masse, D., Gilbert, Y., and Topp, E. (2011). Pathogen removal in farm-scale psychrophilic anaerobic digesters processing swine manure. Bioresour. Technol. 102, 641-646. doi: 10.1016/j.biortech.2010.08.020

Miller, B. D., Rigdon, C. E., Robinson, T. J., Hedberg, C., and Smith, K. E. (2013). Use of global trade item numbers in the investigation of a Salmonella Newport outbreak associated with blueberries in Minnesota, 2010. J. Food Prot. 76, 762-769. doi: 10.4315/0362-028X.JFP-12-407
Murphy, S., Gaffney, M. T., Fanning, S., and Burgess, C. M. (2016). Potential for transfer of Escherichia coli O157:H7, Listeria monocytogenes and Salmonella Senftenberg from contaminated food waste derived compost and anaerobic digestate liquid to lettuce plants. Food Microbiol. 59, 7-13. doi: 10.1016/j. fm.2016.04.006

Natvig, E. E., Ingham, S. C., Ingham, B. H., Cooperband, L. R., and Roper, T. R. (2002). Salmonella enterica serovar typhimurium and Escherichia coli contamination of root and leaf vegetables grown in soils with incorporated bovine manure. Appl. Environ. Microbiol. 68, 2737-2744. doi: 10.1128/ AEM.68.6.2737-2744.2002

Nguyen, T. P., Friedrich, L. M., and Danyluk, M. D. (2014). Fate of Escherichia coli O157:H7 and Salmonella on whole strawberries and blueberries of two maturities under different storage conditions. J. Food Prot. 77, 1093-1101. doi: 10.4315/0362-028X.JFP-13-517

Nicholson, F. A., Groves, S. J., and Chambers, B. J. (2005). Pathogen survival during livestock manure storage and following land application. Bioresour. Technol. 96, 135-143. doi: 10.1016/j.biortech.2004.02.030

Nottingham, P. M., and Urselmann, A. J. (1961). Salmonella infection in calves and other animals. N. Z. J. Agric. Res. 4, 449-460.

Pal, A., and Marshall, D. L. (2009). Comparison of culture media for enrichment and isolation of Salmonella spp. from frozen channel catfish and Vietnamese basa fillets. Food Microbiol. 26, 317-319. doi: 10.1016/j.fm.2008.12.003

Rahn, K., Degrandis, S. A., Clarke, R. C., Mcewen, S. A., Galan, J. E., Ginocchio, C., et al. (1992). Amplification of an invA gene sequence of Salmonella typhimurium by polymerase chain reaction as a specific method of detection of Salmonella. Mol. Cell. Probes 6, 271-279. doi: 10.1016/0890-8508(92)90002-F

Rahube, T. O., Marti, R., Scott, A., Tien, Y. C., Murray, R., Sabourin, L., et al. (2014). Impact of fertilizing with raw or anaerobically digested sewage sludge on the abundance of antibiotic-resistant coliforms, antibiotic resistance genes, and pathogenic bacteria in soil and on vegetables at harvest. Appl. Environ. Microbiol. 80, 6898-6907. doi: 10.1128/AEM.02389-14

Rempel, H. G., Strik, B. C., and Righetti, T. L. (2004). Uptake, partitioning, and storage of fertilizer nitrogen in red raspberry as affected by rate and timing of application. J. Am. Soc. Hortic. Sci. 129, 439-448. doi: 10.21273/ JASHS.129.3.0439

Saunders, O., Harrison, J., Fortuna, A. M., Whitefield, E., and Bary, A. (2012). Effect of anaerobic digestion and application method on the presence and survivability of E. coli and fecal coliforms in dairy waste applied to soil. Water Air Soil Pollut. 223, 1055-1063. doi: 10.1007/s11270011-0923-5

Sheng, L., Shen, X., Su, Y., Tsai, H.-C., Benedict, C., Schacht, E., et al. (2019). Microbial safety of dairy manure fertilizer application in raspberry production. Front. Microbiol. 10:2276. doi: 10.3389/fmicb.2019.02276

Sobsey, M. D., Khatib, L. A., Hill, V. R., Alocilja, E., and Pillai, S. (2006). "Pathogens in animal wastes and the impacts of waste management practices on their survival, transport and fate" in Animal agriculture and the environment: National Center for manure and animal waste management white papers. eds. J. M. Rice, D. F. Caldwell, and F. J. Humenik (St. Joseph, MI: ASABE), 609-666.

Steele, M., and Odumeru, J. (2004). Irrigation water as source of foodborne pathogens on fruit and vegetables. J. Food Prot. 67, 2839-2849. doi: 10.4315/0362-028x-67.12.2839

Strawn, L. K., Fortes, E. D., Bihn, E. A., Nightingale, K. K., Grohn, Y. T., Worobo, R. W., et al. (2013). Landscape and meteorological factors affecting prevalence of three food-borne pathogens in fruit and vegetable farms. Appl. Environ. Microbiol. 79, 588-600. doi: 10.1128/AEM.02491-12

Strik, B. C., Moore, P. P., and Finn, C. E. (2014). Blueberry cultivars for the Pacific Northwest. Available at: https://catalog.extension.oregonstate.edu/sites/ catalog/files/project/pdf/pnw656.pdf (Accessed September 20, 2019).

Tsai, H. C., Ballom, K. F., Xia, S., Tang, J., Marks, B. P., and Zhu, M. J. (2019). Evaluation of Enterococcus faecium NRRL B-2354 as a surrogate for Salmonella during cocoa powder thermal processing. Food Microbiol. 82, 135-141. doi: 10.1016/j.fm.2019.01.005

USDA (1998). Guide to minimize microbial food safety hazards for fresh fruits and vegetables. Available at: https://www.fda.gov/downloads/Food/ GuidanceRegulation/UCM169112.pdf (Accessed November 22, 2019).

USDA (2018). 2017 Census of Agriculture. Retrieved from: https://www.nass. usda.gov/Publications/AgCensus/2017/index.php\#rankings (Accessed September 20, 2019). 
Vargas, O. L., and Bryla, D. R. (2015). Growth and fruit production of highbush blueberry fertilized with ammonium sulfate and urea applied by fertigation or as granular fertilizer. HortScience 50, 479-485. doi: 10.21273/HORTSCI.50.3.479

Weatherunderground (2019). Available at: https://www.wunderground.com/history/ airport/KBLI/?hdf=1 (Accessed Octobor 25, 2019).

Weis, J., and Seeliger, H. (1975). Incidence of Listeria monocytogenes in nature. Appl. Microbiol. 30, 29-32.

Yorgey, G., Frear, C., Kruger, C., and Zimmerman, T. (2014). The rationale for recovery of phosphorous and nitrogen from dairy manure. WSU extension: FS136E. Available at: http://cru.cahe.wsu.edu/CEPublications/FS136E/FS136E. pdf (Accessed September 20, 2019).
Conflict of Interest: The authors declare that the research was conducted in the absence of any commercial or financial relationships that could be construed as a potential conflict of interest.

Copyright (c) 2020 Shen, Sheng, Benedict, Kruger, Su, Schacht, Zhang and Zhu. This is an open-access article distributed under the terms of the Creative Commons Attribution License (CC BY). The use, distribution or reproduction in other forums is permitted, provided the original author(s) and the copyright owner(s) are credited and that the original publication in this journal is cited, in accordance with accepted academic practice. No use, distribution or reproduction is permitted which does not comply with these terms. 